\title{
The risks in the implementation of the Write-Off Ceiling Incentive Policy in retail segment: A case study of ABC Bank
}

\author{
D.V. Astriana \\ Master in Management, Faculty of Economics and Business, University of Indonesia, Indonesia \\ D. Wibowo \\ Dirgantara Marsekal Suryadarma, Faculty of Technology Management \& Technopreneur, \\ Universiti Teknikal Malaysia Melaka, Malaysia
}

\begin{abstract}
The Write-Off Ceiling Incentive Policy is part of the business policies of ABC Bank regarding debt collection. This policy was set in 2011 to reduce the number of Non-Performing Loans (NPLs). In addition, it also motivates account officers in all ABC Bank branch offices to collect the loans and achieve NPL recovery, including the written-off ones. However, this policy also faces certain risks in the banking sector. This study aims to investigate the risks affecting the effectiveness of the policy implementation in $\mathrm{ABC}$ Bank. This study was conducted through a series of interviews and a literature study in September 2020. The results showed that this policy deals with the following risks: (1) operational risk; (2) legal risk; (3) reputation risk; and (4) compliance risk. Therefore, the right risk treatment is required to manage each risk in order to increase the effectiveness of this policy on debt collection.
\end{abstract}

\section{INTRODUCTION}

Lending service is one of the essential businesses for banking institutions conducted by distributing funds to the third party. It is based on the contractual agreement in which the debtor agrees to make the monthly principal and interest repayments at the due date. However, this service can put the bank at credit risk due to the inability of the debtors to fulfill their obligation.

Debtors' failure to fulfill their obligation will cause the occurrence of non-performing loans (NPLs). The occurrence of NPLs decreases the technical efficiency of banking institutions. At the same time, it also increases the moral hazard due to the decline in credit quality and instability in the financial system (Zhang et al. 2016). Therefore, NPLs negatively affect the profitability of the bank (Elekdag et al. 2020; Partovi \& Matousek 2019)

When bad-debts occur, the bank has to take actions of credit settlement, namely rescheduling, reconditioning, restructuring, and liquidation (Triandi 2018). If those actions fail to handle the existing bad-debts, the bank should do the next action, namely writing-off those bad-debts (Hariyani 2010). Writing-off bad-debts means the bank removes a certain amount of bad-debts, namely the NPLs, from the balance sheet. Nevertheless, this removal does not erase the right of the bank to re-collect the removed amount of NPLs.

As one of the notable banks in Indonesia, ABC Bank has prepared the procedures of NPL settlement. One of them is the Write-Off Ceiling Incentive Policy. According to the Directors Decree of ABC Bank in 2011 regarding the breakdown of write-off ceiling in the retail segment, this policy was set to motivate account officers of $\mathrm{ABC}$ Bank in collecting the loans, including the bad-debts or NPLs. If the NPLs can be recovered, the health of the bank, as well as its profit, will get better. Therefore, ABC Bank must anticipate the occurrence of NPLs and encourage its account officers to recover the existing bad-debts. In addition, ABC Bank also has to anticipate the risks 
that may affect the effectiveness of the policy implementation in order to increase the income of NPL recovery.

\section{LITERATURE REVIEW}

\subsection{Credit service in banking institutions}

Act of the Republic of Indonesia Number 10 of 1998 concerning Banking stated that the banking institutions are in charge of collecting funds from people and distributing them for social prosperity. Based on this statement, one of the main functions of banking institutions is to distribute funds in form of credit lending. According to Financial Service Authority Regulation Number 40/POJK.03/2019 regarding the Assessment of Commercial Bank Asset Quality, credit is a lending service (in form of money) between the bank and the third party following a contractual loan agreement. This agreement obligates the debtors to fulfill their obligations regarding the lending contract, including the loan principal, the loan interest, etc.

\subsection{Risks in banking institutions}

According to Financial Service Authority Regulation Number 18/POJK.03/2016 concerning the Implementation of Risk Management for Commercial Bank, the commercial banks are dealing with 8 types of risks, covering:

1. Credit risk, which is a risk of losses due to the third parties' failure to meet their obligations to the banks. Credit risks consist of debtors' failure to meet contractual agreements regarding lending - which causes default and the occurrence of nonperforming loans, counterparty credit risk, and settlement risk. According to Bessis (2015), credit risks consists of the deterioration of the debtors' credit standings - which causes a higher likelihood of default; recovery risks - due to the uncertain recovery values under the default; and counterparty credit risks - the potential occurrence of transaction loss when a party involved defaults.

2. Market risk, which is a risk of losses due to the change of market conditions. According to the Indonesian Bankers Association (2015), market risk is defined as the risk of change in market price in portfolio position and administrative accounts. According to Bessis (2015) market aspects that affect the condition consist of interest rates, equity indexes, or foreign exchange rates.

3. Liquidity risk, which is a risk of losses due to the banks' failure to meet the obligations at the due date from funding sources-cash and its equivalent.

4. Operational risk, which is a risk of loss due to the inadequacy and/or dysfunction of internal processes, human error, system failure, and/or external events that affect bank operations.

5. Compliance risk, which is a risk of losses due to the banks' failure to comply with the regulations, acts, and other requirements for banking institutions. According to the Indonesian Bankers Association (2015), this risk is related to capital adequacy, the valuation of productive assets quality, the impairment of losses reserve, and other risks related to certain policies.

6. Legal risk, which is a risk of losses due to the legal lawsuit and/or weakness in juridical aspects. The causes of legal risks are the unavailability of the constitutional regulations - to support the business policy - and the inadequacy of the contractual binding process (Indonesian Bankers Association (2015).

7. Reputation risk, which is a risk of losses due to the decrease of stakeholders' trust due to the negative perceptions regarding the bank. According to Solvency II, the Comite' Europe's des Assurances (CEA), and the Groupe Consultatif Actuariel Europeen (2007) in Gatzert et al. (2016), reputation risk happens due to business events that trigger the occurrence of adverse publicity, and also from other risks inherent in the business activity.

8. Strategic risk, which is a risk of losses due to the inaccuracy in decision making and failure to anticipate the change in the business environment. 
It is important for banking institutions to have an adequate risk management system to reduce the loss possibility due to the occurrence of risks arising from all Bank's business activities. Indonesian Bankers Association (2015) stated that while it is obligated by the authority, isk management is also necessary for banking institutions to create their value and reach their targets.

\section{RESEARCH METHOD}

This study investigated the risks that affect the effectiveness of the Write-Off Ceiling Incentive Policy implementation in ABC Bank. It is carried out by (1) interviewing three expert panels of $\mathrm{ABC}$ Bank to learn about the practice of the policy as well as the risks, and (2) conducting a literature study to find out the ideal standard of policy implementation based on regulations.

The interviewees, namely the three expert panels of ABC Bank, consist of 2 (two) Executive Vice Presidents and 1 (one) Senior Manager. The tenures of both Executive Vice Presidents are at least twenty years, while that of the Senior Manager is at least ten years. Therefore, they are expected to show their competencies and experiences with this policy.

\section{RESEARCH FINDINGS}

Based on the interview with the representatives of $\mathrm{ABC}$ Bank, it was found that the risks affecting the effectiveness of the Write-Off Ceiling Incentive Policy implementation in ABC Bank are as follow:

1. Operational risk

According to one of the Executive Vice Presidents of ABC Bank, the operational risks are related to the limited number of account officers and the miscommunication between two types of account officers.

"The limited numbers of account officers will result in the work overload, as they are responsible not only for credit collection but also for credit expansion. Therefore, ABC Bank divided its account officers into two types: the marketing account officers and the non-performing loan account officers. However, such division also causes miscommunication."

2. Legal risk

The legal risks are in connection with the occurrence of legal cases during the collection of nonperforming loans. According to the Senior Manager of ABC Bank, the following is an example of legal risk regarding the recollection of NPLs.

"...Such cases occur when a credit settlement requires the auction of the collateral asset, but the debtors are unwilling to give up their assets. This unwillingness causes the debtors to file a lawsuit against ABC Bank. Therefore, the NPL collection has to be postponed until the lawsuit is over."

3. Reputation risk

According to the Senior Manager of ABC Bank, the reputation risks are associated with the uncooperative manner of debtors and the spread of false news.

“...There was a case in which a debtor's house was about to be auctioned. However, s/he refused to leave his/her house. S/he spread false news claiming that s/he was mistreated by $A B C$ Bank, while the truth was that s/he was the one breaching the contracts."

4. Compliance risk

According to one of the Executive Vice Presidents of ABC Bank, compliance risks occur when the authority set regulations prioritizing credit relaxation over credit collection.

"...For example, when the Financial Service Authority released Regulation Number 11/POJK.03/2020 concerning the National Economic Stimulus as a Countercyclical Policy on the Impact of the Covid-19 Pandemic Outbreak, the NPL collection will be less effective than it was during the normal period as the convenience of credit is prioritized. Consequently, the NPL recovery after the release of this regulation will be lower than before." 


\section{CONCLUSION AND SUGGESTION}

It is an undeniable fact that NPLs occur and cannot be avoided by banking institutions. To reduce the number of NPLs to a tolerable range, the Write-Off Ceiling Incentive Policy was set and implemented in ABC Bank. However, some risks affect the effectiveness of the policy implementation in ABC Bank. Those risks are (1) operational risk; (2) legal risk; (3) reputation risk; and (4) compliance risk.

Effective risk management is necessary to reduce the negative impact of those risks on the collection of the NPL recovery. Specific actions are required to handle each risk in the implementation of the Write-Off Ceiling Incentive Policy in order to increase the NPL recovery and the effectiveness of the policy implementation. Operational risk can be reduced by recruiting more account officers and bridging the communication between two types of account officers to reduce the miscommunication. Legal risk can be reduced by making sure that the credit contract is bonded properly, including the administrative files completeness and the documentation during the credit contract binding. Compliance risk can be reduced by setting procedures in credit settlement - based on the regulation - that can benefit both debtors and ABC bank. Meanwhile, reputation risk can be reduced through preventive actions. Further research can be conducted by discussing the risk management process to increase the NPL recovery.

\section{REFERENCES}

Bessis, J., 2015. Risk management in banking.pdf, Fourth. ed. John Wiley \& Sons, West Sussex.

Elekdag, S., Malik, S., Mitra, S., 2020. Breaking the Bank? A Probabilistic Assessment of Euro Area Bank Profitability. J. Bank. Financ. 120, 105949.

Gatzert, N., Schmit, J.T., Kolb, A., 2016. Assessing the Risks of Insuring Reputation Risk. J. Risk Insur. 83, 641-679.

Hariyani, I., 2010. Restrukturisasi dan penghapusan kredit macet. Elex Media Komputindo, Jakarta.

Indonesian Bankers Association (2015). Manajemen Risiko 1. PT Gramedia Pustaka Utama, Jakarta. Otoritas Jasa Keuangan, 2016. Peraturan Otoritas Jasa Keuangan Nomor 18/POJK.03/2016.

Partovi, E., Matousek, R., 2019. Bank efficiency and non-performing loans: Evidence from Turkey. Res. Int. Bus. Financ. 48, 287-309.

Tentang Penerapan Manajemen Risiko Bagi Bank Umum 1-31.Triandi, A., 2018. Analisis Tentang Restrukturisasi Kredit untuk Menghindari Terjadinya Kredit Macet (Studi pada PT). Bank Rakyat. Repos. Institusi USU. Universitas Sumatera Utara.

Zhang, D., Cai, J., Dickinson, D.G., Kutan, A.M., 2016. Non-performing loans, moral hazard and regulation of the Chinese commercial banking system. J. Bank. Financ. 63, 48-60. 